\title{
INCIDENCE OF DEEP VEIN THROMBOSIS IN FLOATING KNEE
}

\section{INCIDÊNCIA DE TROMBOSE VENOSA PROFUNDA EM JOELHO FLUTUANTE}

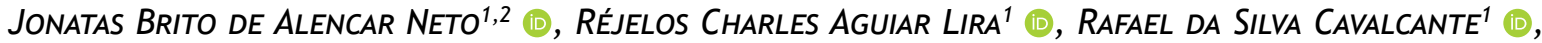 \\ Marcio Bezerra Gadelha Lopes ${ }^{1,2}$ (1), Clododido José Duarte de Sousa ${ }^{1}$ (1), Diego ARIEL de Lima ${ }^{3}$ (1) \\ 1. Instituto Doutor José Frota, Fortaleza, CE, Brazil. \\ 2. Clínica Articular, Fortaleza, CE, Brazil. \\ 3. Universidade Federal Rural do Semi-Árido. Mossoró, RN, Brazil.
}

\section{ABSTRACT}

Objective: To report the incidence of deep vein thrombosis (DVT) in ipsilateral femur and tibial fractures (floating knee). Methods: This is a retrospective, analytical, observational study conducted with the medical records of thirty patients admitted to a trauma hospital between October 2016 and July 2017 with floating knee. Results: Patients aged between 21-30 years were the most affected by the condition (36\%). Seventeen patients affected the dominant limb (57\%); 19 (63\%) patients were classified as Fraser type I, 18 (60\%) had open (compound) fractures, $16(53 \%)$ tibial fractures, and $8(26 \%)$ femoral fractures. External fixation of the femur and tibia (25 patients $=83 \%$ ) was the most common emergency treatment. In total, $17 \%$ of patients presented deep venous thrombosis $(p=0.409)$. Conclusion: Despite antithrombotic prophylaxis, the incidence of DVT in the affected limb of patients with floating knee was high. We found patients with Fraser I fractures, male, and with fractures in the non-dominant limb to present a higher chance of developing DVT. Level of Evidence III, Comparative retrospective study .

\section{RESUMO}

Objetivo: Relatar a incidência de trombose venosa profunda (TVP) em fratura ipsilateral de fêmur e tíbia (joelho flutuante). Materiais e métodos: Realizado um estudo retrospectivo, observacional e analítico por meio da avaliação de prontuários de trinta pacientes admitidos com joelho flutuante em um hospital de trauma durante o período de outubro de 2016 a julho de 2017. Resultados: A faixa etária mais acometida foi entre 21 e 30 anos (36\%). O acometimento do membro dominante ocorreu em 17 (57\%) dos pacientes avaliados. Dezenove (63\%) pacientes acometidos foram classificados como Fraser Tipo I. Dezoito (60\%) pacientes tiveram fratura exposta, sendo 16 (53\%) em tíbia e 8 (26\%) em fêmur. O tratamento mais utilizado como urgência foi o de controle de danos com fixador externo em fêmur e tíbia (83\%). Observamos trombose venosa profunda em $17 \%$ dos pacientes $(p=0,409)$. Conclusão: Apesar do uso da profilaxia antitrombótica medicamentosa, houve uma grande incidência de TVP no membro acometido em pacientes com joelho flutuante na população estudada. As fraturas classificadas como Fraser I, pacientes do sexo masculino e o membro não dominante levaram ao aumento da probabilidade do surgimento de TVP. Nível de Evidência III, Estudo retrospectivo comparativo.

Keywords: Venous Thrombosis. Knee. Trauma. Fractures, Bone.

Descritores: Trombose Venosa. Trauma. Joelho. Fraturas Ósseas.

Citation: Alencar Neto JB, Lira RCA, Cavalcante RS, Lopes MBG, Sousa CJD, Lima DA. Incidence of deep vein thrombosis in floating knee. Acta Ortop Bras. [online]. 2021;29(1):17-20. Available from URL: http://www.scielo.br/aob.

\section{INTRODUCTION}

Deep vein thrombosis (DVT) is a major complication of lower limb fractures ${ }^{1}$ that may incur in death risk, such as for leading to pulmonary thromboembolism. ${ }^{2}$ DVT is directly related to high-energy trauma. ${ }^{3}$ The routine use of anticoagulants in prophylactic doses, such as low-molecular-weight heparin, is the most common among the protocols to avoid such complication. Despite its high cost, this protocol is effective in preventing DVT, reducing treatment costs and avoiding morbidity with considerable death risk or permanent sequelae. ${ }^{4}$
Described by Blake and McBryde in 1975 as floating knee, ${ }^{5}$ ipsilateral fractures of the femur and tibia are associated with high-energy mechanisms of injury, ${ }^{6}$ thus implying a greater association with DVT. Fraser classified floating knee injuries into two types. Whereas type I injuries characterize diaphyseal fractures of the femur and tibia, type II affects the knee joint and is subdivided into three other types: IIA, diaphyseal femur fractures and intra-articular fractures of the tibia; IIB: intra-articular fractures of the femur and diaphyseal tibial fractures; and IIC: intra-articular fractures of the femur and tibia. ${ }^{7}$

All authors declare no potential conflict of interest related to this article.

The study was conducted at the Instituto Dr. José Frota.

Correspondence: Diego Ariel de Lima. R. Francisco Mota, 572, Pres. Costa e Silva, Mossoró, RN, Brazil, 59625900. arieldelima.diego@gmail.com

Article received on 10/27/2019, approved on 07/14/2020. 
This retrospective study aims to investigate the association between deep vein thrombosis (DVT) and ipsilateral fracture of the femur and tibia (floating knee) in patients receiving antithrombotic therapy.

\section{MATERIALS AND METHODS}

This is a retrospective, cross-sectional, analytical study conducted with patients treated at a tertiary referral hospital in Fortaleza - Ceará (CE) Brazil, between October 2016 and July 2017. During this time, 37 patients with floating knee injuries were treated at the hospital. All patients admitted to the hospital and diagnosed with floating knee during the aforementioned period were included in the study. Floating knee was diagnosed based on anteroposterior radiographs (AR) and a profile of the affected limb leg and femur bones.

Patients with prefracture comorbidities that could cause complications (diabetes, thrombophilia, hemophilia, smoking) and with prior history of thromboembolic events were excluded.

After applying the exclusion criteria, 30 patients were eligible to participate in the study.

The following data were collected from patients' medical records: age, gender, affected side, Fraser's fractures classification, mechanism of injury, fracture type (open or closed), fracture treatment at urgent care, definitive fracture treatment, and complications (superficial infection, deep infection, and DVT).

Up from admission, all patients $(n=30)$ received subcutaneous enoxaparin prophylaxis ( $40 \mathrm{mg} /$ day) in prevention of thromboembolic events. If they did not present any complications, the treatment was maintained for 2 months during hospitalization, according to the institution's protocol. After clinical complaints (pain and stiffness), DVT was considered and confirmed with direct venous thrombosis visualization using Doppler ultrasound.

Data were stored in the Statistical Package for the Social Sciences (SPSS, NY, USA) version 18.0 and tabulated in Microsoft Excel 2007 (Microsoft, WA, USA), calculating the frequency of each categorical variable. Pearson's chi-squared test was used for variables associations; $p$-value $<0.05$ was considered statistically significant for all analyses.

The study was approved by the Research Ethics Committee under protocol number 2.259.144, and written informed consent was obtained from the institution Medical Record sector.

\section{RESULTS}

Of the 30 patients assessed, 25 (83\%) were men and 5 (17\%) women. The most affected age range was between 21 and 30 years (36\%). Seventeen patients presented injuries affecting the dominant limb (57\%).

Most patients were classified as type I fractures according to Fraser's classification; that is, extra-articular fractures of the femur and tibia (Figure 1)

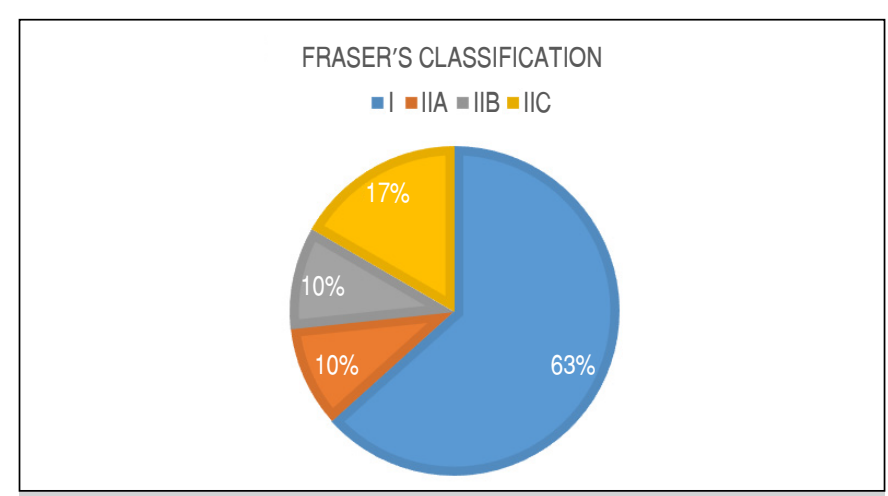

Figure 1. Fraser's classification for the patients studied.
Eighteen (60\%) patients had open fractures, 16 (53\%) tibial fractures, and 8 (26\%) femoral fractures. Regarding the open tibial fractures, five were classified as grade $1,{ }^{8}$ seven as grade II, and six as grade IIIa. As for the open femoral fractures, five were graded II and three IIIa.

External fixation of the femur and tibia was the most used emergency treatment ( 25 patients $=83 \%$ ), and femur plates and extern fixators for the tibia were the most common definitive treatment, used in 7 patients (23\%) (Table 1). One patient suffered clinical complications due to severe infection and soft tissue necrosis; venous Doppler ultrasound examination was performed and pointed to the need for suprapatellar amputation (negative for DVT).

The average time for the definitive treatment was 8.14 days, with a maximum of 22 and minimum of 2 days.

Most patients' (70\%) injuries were due to high-energy motorcycle accident trauma. (Figure 2) (Table 1)

Fracture consolidation time took on average 19.4 (16-25) weeks for the femur and 16.2 (13-20) weeks for the tibia. Two cases presented pseudarthrosis of the femur: one treated with an autologous iliac crest bone graft and one with bone transport. Pseudarthrosis of the tibia occurred in three cases, all treated with autologous bone graft and subsequent consolidation.

Fourteen patients (46\%) suffered infectious complications, nine (30\%) superficial, and five (16\%) deep. Superficial infection was treated with oral antibiotic and local care. When $S$. aureus was identified in culture, deep infection was treated with surgical debridement. Patients underwent endovenous antibiotic therapy for 4 weeks and oral therapy for other 2 , guided by the antibiogram.

One patient suffered vascular lesion of the popliteal artery at trauma and underwent revascularization 3 hours after. The same patient presented DVT and deep infection.

Four patients presented neurological lesion in the the deep fibular nerve and recovered spontaneously after expectant treatment during outpatient follow-up. All were classified as Fraser's type IIC.

Five patients (17\%) were diagnosed with DVT by Doppler ultrasound - cases $3,5,7,11$, and 22 in Table 1 ( $p=0.409)$, - four of which in a deep leg vein and one in a deep thigh vein. All DVT cases were identified between the second and fourth week post-trauma.

All five patients affected by DVT were men ( $p=0.209)$, victims of traffic accident $(p=0.372)$ and treated with an external fixator at emergency care $(p=0.570)$. Conversion to internal synthesis was precluded in two of these patients due to the severe skin damage (cases 3 and 22), so an external fixator was used as definitive treatment. For the other three cases, definitive treatment consisted either of plate/screw on the femur and external fixator in the tibia; osteosynthesis with retrograde intramedullary nailing of the femur; or plate/screw and external fixator in the tibia.

Among patients with DVT, $80 \%$ were classified as type I fractures according to Fraser's classification and $20 \%$ as type IIC $(p=0.480)$. All injuries were caused due to high-energy trauma, $60 \%$ resulting of motorcycle accident and $40 \%$ of automobile accident ( $p=0.372)$.

Four cases were treated with full heparinization (60 mg/day) and one with vena cava filter placement. After DVT diagnosis and treatment, cases converted for internal synthesis underwent surgery upon authorization of the institution vascular surgery team. 
Table 1. Demographic profile, injury pattern, fixation method, and complications.

\begin{tabular}{|c|c|c|c|c|}
\hline Variables & Tibial fractures & $\begin{array}{c}\text { Femoral } \\
\text { fractures }\end{array}$ & All patients & $p$-value \\
\hline $\begin{array}{l}\text { No. of patients } \\
\text { (men/women) }\end{array}$ & & & $30(26 / 4)$ & 0.209 \\
\hline Age & & & $\begin{array}{c}34.7 \\
( \pm 12-72 \text { years })\end{array}$ & 0.452 \\
\hline Trauma mechanism & & & & 0,372 \\
\hline MVA & & & 28 & \\
\hline GSW & & & 1 & \\
\hline Fall from height & & & 1 & \\
\hline Affected limb (R/L) & & & $21 / 9$ & \\
\hline Dominant limb & & & 17 & 0.412 \\
\hline $\begin{array}{l}\text { Associated injuries } \\
\text { (patients with } \\
\text { associated injury) }\end{array}$ & & & $31(19)$ & \\
\hline $\begin{array}{l}\text { Fractures in } \\
\text { other bones }\end{array}$ & & & 11 & \\
\hline TBI & & & 8 & \\
\hline Pelvic injury & & & 3 & \\
\hline Chest trauma & & & 3 & \\
\hline Abdominal trauma & & & 2 & \\
\hline Facial trauma & & & 2 & \\
\hline Spinal injury & & & 1 & \\
\hline Other injuries & & & 1 & \\
\hline $\begin{array}{l}\text { Period between } \\
\text { admission and } \\
\text { first surgery }\end{array}$ & & & 1.21 days & \\
\hline Fracture pattern & & & & 0.480 \\
\hline Closed & 14 & 22 & & \\
\hline Open & 16 & 8 & & \\
\hline Type I & 2 & & & \\
\hline Type II & 8 & 5 & & \\
\hline \multicolumn{5}{|l|}{ Type III } \\
\hline$A$ & 4 & 3 & & \\
\hline$B$ & 1 & & & \\
\hline C & 1 & & & \\
\hline $\begin{array}{l}\text { Fixation method } \\
\text { at urgent care }\end{array}$ & & & & 0.570 \\
\hline $\begin{array}{c}\text { Isolated Ex Fix } \\
\text { Transarticular Ex Fix }\end{array}$ & $1 / 25$ & $1 / 25$ & & \\
\hline \multicolumn{5}{|l|}{ HIM } \\
\hline Plate & 1 & 1 & & \\
\hline Plaster splint & 3 & 3 & & \\
\hline Conversion time & & & $\begin{array}{c}8.14 \\
( \pm 2-22 \text { days })\end{array}$ & \\
\hline $\begin{array}{c}\text { Definitive } \\
\text { fixation method }\end{array}$ & & & & 0.266 \\
\hline External fixator & 12 & 10 & & \\
\hline IM Nailing & 4 & 7 & & \\
\hline Plate & 12 & 12 & & \\
\hline Plaster cast & 1 & & & \\
\hline Amputation & 1 & 1 & & \\
\hline Consolidation time & $\begin{array}{c}16.2 \\
( \pm 13-20 \text { months })\end{array}$ & $\begin{array}{c}19.4 \\
( \pm 16-25 \text { months })\end{array}$ & & \\
\hline \multicolumn{5}{|l|}{ Complications } \\
\hline DVT & 4 & 1 & 5 & 0.409 \\
\hline Infection & & & 14 & 0.193 \\
\hline Superficial & & & 9 & \\
\hline Deep & & & 5 & \\
\hline Pseudoarthrosis & 3 & 2 & 5 & \\
\hline Vascular lesion & & & 1 & \\
\hline Neurological lesion & & & 4 & \\
\hline
\end{tabular}

MVA: motor vehicle accident; GSW: gunshot wound; TBI: traumatic brain injury; Ex Fix: external fixator; IM: intramedullary nail; DVT: deep vein thrombosis.

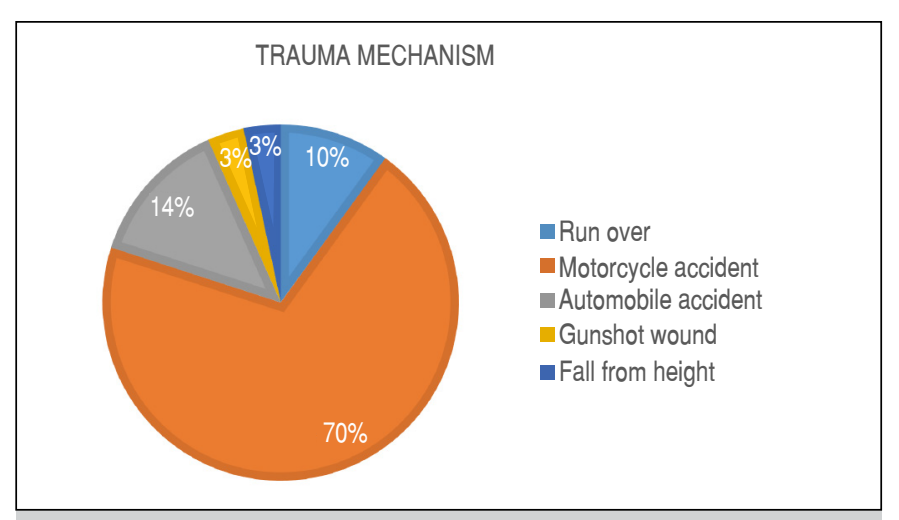

Figure 2. Patients with floating knee according to trauma mechanism.

\section{DISCUSSION}

Our results indicate that male patients with fractures classified as Fraser's type I are more likely to develop deep vein thrombosis (DVT) and exhibit high indices of associated injury. Besides other fractures, uncommon injuries of unknown incidence, these patients also present a higher risk for organ damage, possibly leading to death. ${ }^{9}$ Most of our study participants were men in their 30s, corroborating a previous study that found a higher prevalence of men (85\%) in their 30s (45\%) among 238 cases of floating knee.

In our study, most patients with floating knee were victims of high-energy traffic accident trauma, primarily involving motorcycles. These data corroborate those of Rethnam, Yesupalan, and Nair, ${ }^{10}$ who likewise found 27 of 29 floating knee cases to result from traffic accidents. Another retrospective study conducted with 172 patients with floating knee found $71.5 \%$ to be classified as type I, $8.2 \%$ as IIA, $11.2 \%$ IIB ,and $8.7 \%$ as IIC according to Fraser's classification. ${ }^{11}$ These findings corroborate ours, since most cases in our study were classified as type I (63\%).

Most patients were treated with external fixation at urgent care, possibly due to their severity at arrival, since most were victims of high-energy trauma (Table 1). De Marco, Rozim, and Piedade ${ }^{12}$ reported similar results, in which $64.71 \%$ of patients with floating knee were treated with external fixation to stabilize fractures at hospital arrival. When studying 125 patients with lower limb fracture, Kapoor et al. ${ }^{13}$ found six cases to be positive for DVT. Among the 47 patients with periacetabular fractures, four (8.51\%) developed DVT and eight sustained floating knee, two of whom eventually developed DVT. None of these patients received antithrombotic prophylaxis. In our study, the incidence of DVT in patients with floating knee was $17 \%$, even with antithrombotic prophylaxis.

Within our study sample, the analyzed variables (gender, dominant limb affected, Fraser classification, trauma mechanisms, and emergency treatment) were not statistically significant risk factors for patients with floating knee to develop DVT.

According to Donath et al., using fondaparinux in antithrombotic prophylaxis resulted in a higher number of distal thrombotic events than enoxaparin in the context of orthopedic surgery. ${ }^{14}$ However, we found no statistical significance for this association.

The early diagnosis and treatment of DVT may play a key role in minimizing complications related to this condition. ${ }^{15}$ In our study, the five patients diagnosed by venous Doppler ultrasound exhibited no symptoms of pulmonary thromboembolism.

Considering this is a retrospective study, our main limitation is related to the short follow-up. Using an external fixator at emergency treatment was also a negative factor for promoting a prolonged restriction and immobilization ${ }^{16}$ and not verifying the presence of other associated lesions, such as knee ligament injuries. Moreover, 
given that the Doppler ultrasound was only used in symptomatic cases, the incidence found may be higher.

Our study comprises a large number of cases of an infrequent lesion with a significant amount of data. In the near future, we plan to conduct a prospective randomized study with a larger number of cases.

\section{CONCLUSION}

Regardless of the use of antithrombotic prophylaxis, the incidence of deep vein thrombosis was high among patients with floating knee. Patients with Fraser type I fractures, male, and with the non-dominant limb affected are more likely to develop DVT.

AUTHORS' CONTRIBUTIONS: Each author contributed individually and significantly to the development of this article. JBAN: data acquisition, analysis, and interpretation and writing of the manuscript; RCAL: substantial contribution to the manuscript design; RSC: data acquisition, analysis, and interpretation and writing of the manuscript; MBGL: substantial contribution to the manuscript design; CJDS: writing, critical review of the content, and approval of the final version of the manuscript; DAL: writing, critical review of the content, and approval of the final version of the manuscript.

\section{REFERENCES}

1. Blackwell JR, Javal P, Quicley JP, Patel A, Mcbride D. Patient compliance with venous thromboembolism prophylais (VTE), J Clin Orthop Trauma. 2017;8(2):201-5.

2. Park MS, Owen BA, Ballinger BA, Sarr MG, Schiller HG, Zietlow SP, et al. Quantification of hypercoagulable state after blunt trauma: microparticle and trombin generation are increased relative to injury severity, while stardand markers are not. Surgery. 2012;15:831-6.

3. Testnoote M, Stiger WAH, Janssen L, Janzing HMJ, Low molecular weigth heparine for prevention of venous thomboembolism in patient with lower-leg immobilization. Cochrane Database Syst Rev. 2014;25(4):CD006681.

4. Probe R, Ciceri D. Venous thromboembolic disease in patients with skeletal trauma. In: Tornetta III P, Ricci WM, Ostrum RF, McQueen MM, McKee MD, Court-Brown, CM, editors. Rockwood and Green's fractures in adults. 8a ed. Philadelphia: Lippincott Raven Publishers; 2015. p. 767-77.

5. Blake R, McBryde A. The floating Knee: ipsilateral fractures of the tibia and femur. South Med J. 1975;68:13-6.

6. Muñoz Vives K, Bel JC, Capel AA, Rodriguez FC, Traver JP, Schultz-Larsen $M$, et al. The Floating Knee: a review on ipsilateral and tibial fractures. EFORT Open Rev. 2016;1:375-82.

7. Fraser RD, Hunter GA, Waddell JP. Ipsilateral fracture of the femur and tibia. J Bone Joint Surg Br. 1978;60-B(4):510-5.

8. Gustilo RB, Anderson JT. Prevention of infection in the treatment of one thousand and twenty-five open fractures of long bones: retrospective and prospective analyses. J Bone Joint Surg Am. 1976;58:453-8.
9. Yadav, V, Suri HS, Vijayvargiya M, Agashe V, Shetty V. "Floating Knee," an Uncommon Injury: Analysis of 12 Cases. Rev Bras Ortop. 2019;54(1):53-9.

10. Rethnam U, Yesupalan, RS, Nair R. The floating knee: epidemiology, prognostic indicators \& outcome following surgical management. J Trauma Manag Outcomes. 2007;1(1):2.

11. Pietú, G, Feron JM, Bonneviale P, Jacquort F. Traumatic Floating Knee: A Review of a Multi-Centric Series of 172 Cases in Adult. Open Orthop J. 2015; (suppl 1 M11):356-60.

12. De Marco FA, Rozim AZ, Piedade SR. Estabilidade articular do joelho no quadro do "joelho-flutuante". Acta Ortop Bras. 2008:16(1):32-6.

13. Kapoor CS, Mehta AK, Patel K, Golwala PP. Prevalence of deep vein thrombosis in patients with lower limb trauma. J Clin Orthop Trauma. 2016;7(suppl 2):220-4.

14. Donath L, Lutzner J, Werth S, Kuhlisch E, Albrecht H, Gunther KP, et al. Efficacy and safety of venous thromboembolism prophylaxis with fondaparinux or low molecular weight heparin in a large cohort of consecutive patients undergoing major orthopaedic surgery- findings from the ORTHO-TEP resgitry. Br J Clin Pharmacol. 2012;74(6):947-58.

15. Becattini C, Cohen AT, Geancario A, Howard L, Cartejon B, Trujillo-Santos J, et al. Risk Stratification of Patients With Acute Symptomatic Pulmonary Embolism Based on Presence or Absence of Lower Extremity DVT: Systematic Review and Meta-analysis. Chest. 2016;149(1):192-200

16. Kulkarni MS, Aroor MN, Vijayan S, Shetty S, Tripathy SK, Rao SK. Variables affecting functional outcome in floating knee injuries. Injury. 2018;49(8):1594-601. 